\title{
Grandfather Clause
}

National Cancer Institute

\section{Source}

National Cancer Institute. Grandfather Clause. NCI Thesaurus. Code C78445.

An exemption based on circumstances existing prior to the adoption of some policy. 